\title{
KONTRIBUSI MASJID AMALBAKTI MUSLIM PANCASILA (YAMP) DALAM PEMBANGUNAN MASYARAKAT MUSLIM DI KOTA AMBON
}

\author{
Nur Khozin, M.Pd.I \& Dr. Hasan Lauselang, M.Ag \\ Email: khozinpai@gmail.com
}

\begin{abstract}
A mosque is a religious institution that is inseparable from the spiritual, social and cultural life of the people. Where there are Muslims, there must be a mosque there, the mosque is also a symbol of Islam, if there is a mosque then there is allegedly a Muslim community. Mosques have a big enough role for society, not only as places of worship, but also as centers of civilization for Muslims. The results showed that the history of the YAMP Mosque in Maluku Province, there are 6 mosques. There are 4 units in Ambon City, namely 1 at the IAIN Ambon Campus, 1 at the UNPATTI Campus, 1 in Tihu/Perumnas Poka Village, and 1 at BTN Wayame. Meanwhile, one more mosque is located in Southeast Maluku Regency to be precise next to the Tual City Regional Hospital, another mosque is located in Banda Naira Tanah Rata. As well as the model of prospering the YAMP mosque by the takmir of the mosque or the surrounding community besides worship, Islamic studies are carried out, discussions and also social activities that are useful for the community and members of the YAMP mosques in Ambon city. The community's response to the YAMP mosque is very much needed because of its good existence, and it really helps the worship process as well as to get closer to God Almighty. In addition, the YAMP mosque is very well designed because in the delivery of sermons and recitations it is not obstructed by pillars in the main room so that it is clear that it is clear who delivers the sermon and / or who provides the material. The contribution of the YAMP mosque in the development of the Muslim community in Ambon city is very good, this can be seen from the routine studies carried out by both mosque administrators and religious groups, both routine studies, breaking fast together, cutting sacrificial animals, other religious discussions. in building the country in the future the better. In addition, the YAMP mosque has majlis ta'lim, TPQ, PAUD / RA and MIT. This has been around for a long time.
\end{abstract}

Keywords: Mosque Contribution (YAMP), Community Development

\section{ABSTRAK}

Masjid merupakan pranata keagamaan yang tidak terpisahkan dari kehidupan spiritual, sosial, dan kultural umat. Dimana ada umat Islam pasti di situ ada masjid, masjid juga merupakan simbol keislaman, jika ada masjid maka di situpun disinyalir ada masyarakat muslim. Masjid memiliki peran yang cukup besar bagi masyarakat, bukan hanya sebagai tempat ibadah, melainkan juga sebagai pusat peradaban bagi umat Islam. Hasil penelitian menunjukkan bahwa sejarah Masjid YAMP yang berada di Provinsi Maluku terdapat 6 buah masjid. Keberadaanya 4 buah di Kota Ambon yaitu 1 buah di Kampus IAIN Ambon, 1 buah di Kampus UNPATTI, 1 buah di Kelurahan Tihu/Perumnas Poka, dan 1 buah di BTN Wayame. Sedangkan 1 masjid lagi berada di Kabupaten Maluku Tenggara tepatnya di samping RSUD Kota Tual, 1 masjid lagi diberada di Banda NairaTanah Rata. Serta Model memakmurkan masjid YAMP oleh takmir masjid atau masyarakat sekitar selain ibadah, dilakukannya kajian-kajian keislaman, diskusi-diskusi dan juga kegiatan-kegiatan sosial yang 
berguna untuk masyarakat serta jamaah masjid masjid YAMP di kota Ambon. Tanggapan masyarakat tentang keberadaan masjid YAMP sangat dibutuhkan karena keberadaannya yang baik, dan sangat membantu proses ibadah sekaligus mendekatkan diri mereka terhadap Tuhan Yang Maha Esa. Selain itu juga masjid YAMP sangat baik desainnya karena dalam penyampaian khotbah maupun pengajian tidak dihalangi oleh tiang-tiang di ruang utama sehingga jelas kelihatan yang menyampaikan khutbah dan atau yang memberikan materi. Kontribusi masjid YAMP dalam pembangunan masyarakat Muslim di kota Ambon sangat baik hal ini bisa dilihat dari kajian-kajian rutin yang dilaksanakan baik pengurus masjid maupun majelis ta'lim baik itu kajian rutin, buka puasa bersama, memotong hewan qurban, diskusi-diskusi keagamaan yang lain dalam membangun negara kedepan semakin baik. Selain itu juga masjid YAMP memiliki majlis ta'lim, TPQ, PAUD/RA dan MIT ini sudah berjalan lama.

Kata Kunci : Kontribusi Masjid (YAMP), Pembangunan Masyarakat

\section{PENDAHULUAN}

Masjid bukan sekedar tempat sujud dan sarana penyucian diri dari hadas atau dosa saja, namum juga memiliki fungsi sosial. Fungsinya adalah tempat proses pendidikan, terutama pendidikan keagamaan, pengajian dan kegiatan-kegiatan sosial lainnya. Selain itu masjid sebagai institusi politik dan pemerintahan, karena disana dilangsungkan berbagai musyawarah politik, latihan militer, dan administrasi negara. Lembaga-lembaga pendidikan Islam bermula dari masjid (Dahlan, 1996). Fungsi masjid cukup luas dalam memberikan kontribusi pembangunan masyarakat, tidak hanya sebagai sarana ibadah dan penyucian dosa saja, tetapi dalam bidang pendidikan, sosial, politik, serta masalah kenegaraan diselesaikan atau dimusyawarahkan di masjid. Tak jarang kita menemukan sekolah-sekolah yang berada di sekitar masjid, karena dari masjid itulah lembaga-lembaga pendidikan tumbuh dan berkembang.

Nursaid mengatakan pendidikan Islam sebagai subsistem pendidikan nasional perlu melakukan perubahan paradigma dalam pendidikan, paling tidak pendidikan akan berpengaruh terhadap perubahan pada masyarakat. Proses perubahan paradigma yang mengarah pada perubahan sistem pendidikan harus dilakukan secara terencana dengan langkah-langkah yang strategis, yaitu mengidentifikasi berbagai problem yang menghambat 
terlaksananya pendidikan dan merumuskan langkah-langkah pembaruan yang lebih bersifat strategis dan praktis sehingga dapat diimplementasikan di lapangan atau lebih bersifat operasional. (Nursaid dan Nur Khozin, 2019: 121-147).

Masjid merupakan tempat terbaik untuk kegiatan pendidikan. Dengan menjadikan lembaga pendidikan dalam masjid akan terlihat hidupnya sunahsunah Islam, menghilangkan bid'ah-bid'ah, mengembangkan hukum-hukum tuhan, serta menghilangnya stratifikasi rasa dan status ekonomi dalam pendidikan, maka dengan demikian masjid sudah merupakan lembaga kedua setelah keluarga, yang jenjang pendidikannya terdiri dari sekolah menengah dan sekolah tinggi dalam waktu yang sama. Oleh sebab itu implikasi masjid sebagai lembaga pendidikan Islam adalah menjadikan masjid sebagai lembaga pendidikan, maka dapat menjadi tempat mendidikan anak agar tetap beribadah, cinta ilmu pengetahuan, menanamkan solidaritas, menyadarkan kewajiban-kewajiban sebagai makhluk beragama, serta memberikan rasa tentram rohaninya, menambah kesabaran, perenungan, dan pengadaan penelitian (Abdurahman, 1979).

Pada zaman dahulu telah diselengarakan dua macam strata pendidikan, yaitu pendidikan dasar, yang disebut pengajian Al-Quran dan yang ke dua adalah pendidikan tingkat lanjutan yang disebut guru kitab. Adapun cara yang dipergunakan dalam belajar dan mengajar di masjid dapat dilihat dengan ciri-ciri antara lain anak-anak belajar dengan duduk dalam keadaan bersila tanpa mempergunakan bangku dan meja, demikian pula halnya dengan guru. Mereka belajar dengan guru seorang demi seorang dan belum berkelas-kelas seperti sekolah-sekolah yang ada sekarang. Materi pelajarannya sangat bervariasi, tergantung pada potensi dan kemampuan anak-anak. Namun, pada dasarnya setiap anak memulai pelajarannya dari huruf hijaiyah, mereka mempelajari huruf hijaiyah dengan membaca (mengahafal dan mengenal hurufnya) satu per satu, baru kemudian dirangkaikan, mereka tidak belajar menuliskan huruf- huruf tersebut. Setelah pandai membaca surat-surat pendek terutama yang ada di juz Amma, baru 
diperkenankan membaca Al-Qur'an dari permulaan secara berturut-turut sampai khatam (Iskandar, 2014).

Demikianlah kedudukan masjid sebagai lembaga pendidikan Islam. Untuk kondisi zaman sekarang ini keberadaannya sangat urgen. Sebagai contoh, kalau dahulu ramadhan tiba, biasanya diisi dengan tadarusan AlQur'an, namun sekarang tampaknya berkembang lagi, biasanya tiba ramadhan masjid ramai-ramai mengadakan kegiatan seperti pesantren ramadhan, pesantren kilat, ceramah-ceramah keagamaan, kajian subuh, berbagai macam perlombaan dan lain sebagainya, dan terlebih di dukung oleh pemuda masjid yang penuh dengan kreatif, sehingga masjid lebih semarak, sehingga pemanfaatan masjid lebih terasa. Oleh karena pemanfaatan masjid semakin meningkat, maka pembangunan masjid pun meningkat di semua wilayah di Indonesia.

Selain itu pembangunan masjid biasanya tidak pernah lepas dari campur tangan pemerintah, terutama berkaitan dengan dana pembangunan karena untuk membangun sebuah masjid memerlukan dana yang tidak sedikit. Begitu pula pemerintahan Orde Baru (ORBA) yang berdiri selama 32 tahun telah membawa banyak perubahan bagi pembangunan Indonesia, salah-satunya adalah pembangunan masjid-masjid yang tersebar di seluruh Indonsia. Masjid-masjid yang dibangun adalah atas prakarsa presiden Indonesia kedua yaitu H. M. Soeharto melalui Yayasan Amalbakti Muslim Pancasila (YAMP) yang direncanakan akan membangun masjid sebanyak 999 tersebar di seluruh provinsi di Indonesia. YAMP juga membantu pembangunan masjid Al Hikmah (Indonesian Muslim Community) di New York Amerika Serikat dan masjid "Port Moresby Central Moslem" di Port Moresby Papua New Guenia. Masjid-masjid dibangun menggunakan anggaran Bantuan Presiden (Banpres)/dana APBN/APBD atau bantuan pribadi Presiden Soeharto di luar YAMP.( http://soeharto.co/daftar-masjidyayasan-amalbhakti-muslim-pancasila-yamp-provinsi-sumatera-selatan). Ada juga yang mengatakan bahwa anggaran pembangunan masjid Yayasan 
Amalbakti Muslim Pancasila ini di ambil dari potongan gaji para PNS pada masa itu.

Provinsi Maluku khususnya di kota Ambon terdapat 4 unit masjid YAMP yang berlokasi di kampus IAIN Ambon, kampus UNPATTI, kampung Tihu, dan BTN Wayame. Sebagian masjid-masjid ini telah mengalami perkembangan, penambahan bangunan, renovasi, ada yang berkembang menjadi yayasan sendiri sehingga memiliki lembaga pendidikan, dan pastinya tetap konsisten menjadi lembaga dakwah dalam membagun masyarakat yang Islami.

Peneliti melihat beberapa kegiatan yang selalu rutin dilakukan di masjid Yayasan Amalbakti Muslim Pancasila. Dosen, mahasiswa, bahkan juga masyarakat umum menggunakan masjid sebagai lembaha dakwah peningkatan iman dan takwa. Mahasiswa menjadikan masjid sebagai sekretariat, tempat rapat, tempat pembinaan, dan lain sebagainya.

Selain itu masjid YAMP ini menarik untuk diteliti karena beberapa hal: 1). Masjid YAMP memiliki bentuk dan karakter yang sama diseluruh Indonesia; 2). Dana pembangunan masjid bukan dari masyarakat sekitar, tetapi berasal dari YAMP sendiri, masyarakat setempat hanya menyediakan Iahan untuk pembangunan masjid; 3). Masjid ini memiliki nilai historis tersendiri karena diresmikan langsung oleh presiden soeharto sebagai inisiator; 4). Memiliki kontribusi dalam membangun masyarakat muslim Indonesia.

Didiek Suharjanto dkk dengan judul "Kinerja Termal pada masjid Yayasan Amalbakti Muslim Pancasila" Dari penelitian ini ditemukan bahwa ada kesesuaian atau kenyamanan untuk masjid tipe 15 bila dibangun di daerah dataran rendah seperti Surabaya. Penelitian ini hanya fokus tentang tingkat efektifitas elemen pembentukan termal terhadap kinerja termal bangunan masjid Yayasan Amalbakti Muslim Pancasila dan tidak membahas unsur-unsur lainnya (Suharjanto, 2017). Penelitian ini tidak menyentuh bidang pendidikan atau pembangunan masyarakat. 
Dhani Mutiari, Suryaning Setyowati, Nur Rahmawati Syamsiyah menulis artikel dengan judul Masjid-Masjid Muhammadiyah Yogyakarta menjelaskan tentang sejarah pada masa era Soeharto (tahun1980-an) bahwa image tentang masjid Yayasan Amalbakti Muslim Pancasila sudah terbentuk di masyarakat. Ciri utama masjid ini adalah atap susun tiga, geometri ruang persegi, tempat wudhlu pria dan wanita terpisah, disisi Utara dan Selatan masjid. Akses masuk ruang sholat dari tiga sisi bangunan, Timur, Utara dan Selatan. Masjid berkesan monumental, sebab berada di tengah halaman luas dan dibuat lebih tinggi dari tanah. Dengan ciri seperti itu pada umumnya masyarakat secara langsung dapat menyebut masjid Yayasan Amalbakti Muslim Pancasila sesuai yang dimaksud, dengan hanya melihatnya saja (Mutiari, 2014).

Begitu pula penelitian yang dilakukan Indal Abror dengan judul Akulturasi Nilai-Nilai Budaya Masjid Pathok Negoro Jogjakarta. Masjid Pathok Negoro adalah peninggalan budaya dan agama yang sangat momumental bagi Daerah Istimewa Yogyakarta (DIY). Sebagai pewaris kejayaan Mataran Islam Yogyakarta menjadi wilayah dengan nilai religiusitas yang kental serta pemegang tradisi Jawa yang sangat kuat hingga saat ini. Penelitian ini membahas tentang nilai-nilai dari simbol-simbol yang tersimpan di masjid Pathok Negoro Yogyakarta yang memiliki pesan penting bagi generasi modern sekarang ini, apakah pesan-pesan ini dipahami oleh generasi sekarang atau sudah dilupakan bahkan ditinggalkan (Indah, 2016).

Dari tiga hasil penelitian terdahulu tersebut, dapat kita tarik benang merah bahwa penelitian yang dilakukan oleh Didiek Suharyanto dkk tentang efektifitas termal yakni kondisi udara masjid karena didasari oleh latar belakang pendidikan peneliti, dan belum menyentuh terkait dengan kegiatankegiatan pengurus masjid YAMP terhadap masyarakat, maka penelitian tentang kontribusi masjid Yayasan Amalbakti Muslim Pancasila yang akan dilakukan juga berdasarkan latar belakang pendidikan peneliti yang lebih dekat pada bidang pendidikan, sehinggi peneliti nantinya lebih fokus melihat 
kontribusi masjid Yayasan Amalbakti Muslim Pancasila pada bidang pendidikan.

Dari penelitian Dhani Mutiari, Suryaning Setyowati, Nur Rahmawati Syamsiyah ini kita bisa mengetahui bagaimana karakter masjid-masjid di bawah Yayasan Muhammadiyah khususnya di kota Yogyakarta, sebagai tempat lahirnya Muhammadiyah, yang berlatar belakang budaya Jawa, sehingga kita bisa lebih mengenal sejarah masjid Yayasan Amalbakti Muslim Pancasila di Maluku yang notabene berbeda budaya. Bisa jadi cara untuk memakmurkannya pun berbeda pula, dan dalam memaknai simbol-simbol benda yang ada di masjid mungkin berbeda pula.

Sedangkan penelitian Indal Abrar ini membahas tentang nilai-nilai yang terkandung dalam simbol-simbol yang terdapat di masjid Pathok Negoro, sehingga penelitian ini dapat dijadikan bahan perbandingan dalam memaknai simbol-simbol yang ada di masjid Yayasan Amalbakti Muslim Pancasila.

\section{TINJAUAN TEORI}

\section{Pengertian Kontribusi}

Mengutip secara bahasa kontribusi berasal dari bahasa Inggris yaitu contribute, contribution, maknanya adalah keikutsertaan, keterlibatan, melibatkan diri maupun sumbangan. Makna kontribusi menurut kamus besar bahasa Inggris tersebut adalah dalam bentuk materi atau tindakan. Dalam hal makna yang bersifat materi contohnya adalah apabila ada satu pihak memberikan pinjaman kepada pihak lain untuk kebaikan. Sedangkan kontribusi dalam arti tindakan adalah perilaku yang dilakukan oleh pribadi yang dapat memberikan dampak baik maupun buruk yang berkaitan dengan pihak lain (Ahira, 2012).

\section{Sejarah Masjid}

Secara etimologi, kata masjid berasal dari bahasa Arab, kata pokoknya sujudan, fi'il madhinya sajada (dia telah sujud) lalu menjadi isim makan al-masjidu, yang berarti tempat sujud. Dalam Kamus Besar Bahasa 
Indonesia masjid berarti rumah atau bangunan tempat beribadah orang Islam (KBBI, 2008).

Secara terminology untuk mendapatkan makna "masjid" yang integral, maka harus ditinjau dari berbagai segi, dari historis dan filosofis. Hal ini sebagaimana di katakan Mukti Ali (1987), bahwa masjid hendaknya dipahami sebagai bagian dari masyarakat sekitarnya.

Pengertian masjid sebagaimana disebut di atas, relevan dengan sifat Islam yang universal, eksternal dan berkeseimbangan. Islam yang kosmopolit (sebagai rahmatan li al 'alamiin) meliputi berbagai dimensi hidup dan kehidupan manusia. Sedangkan masjid adalah pusat kegiatan keagamaan umat Islam. Oleh karena itu masjid bukanlah semata-mata sebagai simbol kemegahan dan keberadaan umat Islam yang tidak memberi pengaruh kepada lingkungan kehidupan kaum Muslimin, tetapi persoalan masjid adalah persoalan yang menyangkut kualitas kehidupan umat Islam. Hal ini terbukti strategi yang digunakan Rasulullah Muhammad SAW, dalam melakukan perjalanan ke Madinah, langkah yang diambil adalah membangun masjid, bukan membangun pasar, dan masjid yang dibangun adalah masjid Quba di Madinah.

\section{Masjid Sebagai Tempat Pendidikan Islam}

Dalam perspektif Islam pendidikan nasional, dikenal adanya dua jalur penyelanggaraan pendidikan, yaitu jalur pendidikan sekolah (sekolah formal) dan jalur pendidikan luar sekolah (pendidikan nonformal dan informal). Kedua jalur pendidikan tersebut saling komplementer dalam sistem pendidikan nasional (Tilaar, 1992). Dalam hal pendidikan luar sekolah ini, pelaksanaannya tidak seperti pendidikan jalur sekolah formal. Ciri khas yang paling menonjol dari pendidikan luar sekolah ini adalah memiliki keluwesan tersendiri berkenaan dengan waktu dan lama belajar, usia peserta didik, isi pelajaran cara penyelenggaraan pengajaran dan cara penilaian hasil evaluasinya.

Pendidikan Agama Islam di Indonesia yang diselengarakan di masjid telah disiyaratkan dan diakui eksistensinya secara yuridis-formal. Dengan 
kata lain, masjid sebagai salah satu lembaga pendidikan keagamaan di luar sekolah-formal, telah mendapat pengakuan atau legitiminasi secara yuridisformal, untuk menyelenggarakan dan mengembangkan pendidikan agama Islam. Oleh karena itulah bagaimana sekarang mewujudkan masjid sebagai alternativ pengembangan pendidikan agama Islam, yang sudah memiliki pengakuan sah jalur luar sekolah sebagaimana tersebut di atas (Mukti, 2017).

Menurut Fuad Yusuf dalam Jumaeda dkk, Guru merupakan salah satu faktor yang sangat penting dalam meningkatkan kualitas pendidikan, khususnya Guru Pendidikan Agama Islam, karena disamping mempunyai peran mentransfer ilmu, guru PAI juga mempunyai peran dalam membantu proses internalisasi moral kepada siswa. (Jumaeda dkk, 2018: 28-38). Maka perlu memberikan bantuan pendidikan baik secara formal maupun nonformal, baik di masjid maupun di sekolah untuk peningkatan dan pengembangan pendidikan agama Islam.

Masjid, dalam perspektif pendidikan nasional di Indonesia adalah merupakan wadah atau lembaga pendidikan Islam yang akomodatif terhadap apersepsi umat Islam dan berorientasi kepada pelaksanaan misi Islam melalui tiga dimensi pengembangan kehidupan manusia, yaitu: 1). Dimensi kehidupan ukhrawi yang mendorong manusia untuk mengembangkan dirinya dalam pola hubungan yang serasi dengan Tuhannya. 2). Dimensi duniawi yang mendorong manuisa sebagai hamba Tuhan untuk mengembangkan diri, 3). inya dengan ilmu pengetahuan, keterampilan, dan nilai-nilai Islam. 4). Dimensi kausalitas hubungan dunia dan akhirat yang mendorong manusia untuk berusaha menjadikan diri-nya sebagai hamba yang utuh dan paripurna dalam ilmu dan amal, serta sekaligus menjadi pendukung dan pelaksanaan nilai-nilai Islam.

Dimensi pengembangan lembaga-lembaga pendidikan Islam termasuk masjid sebagaimana di atas adalah berpijak untuk mencapai citacita yang ideal, yaitu identitas Islam dijadikan sebagai daya pokok dari tugas 
dan tanggung jawab budaya edukatif lembaga pendidikan seperti masjid tersebut.

Untuk merealisasikan tiga dimensi pengembangan hidup seorang Muslim, masjid sebagai lembaga pendidikan Islam perlu mengadakan pembinaan berbagai keterampilan dan pemantapan keimanan dari masyarakat agar mereka selalu memanfaatkan apa saja sebagai sumber belajar, di mana hal itu sesuai dengan tanggung jawab masyarakat terhadap pendidikan, yaitu bagaimana maing-masing anggota masyarakat ikut berpartisipasi menciptakan suatu system pendidikan dalam masyarakat sehingga mendorong anggota masyarakat untuk mendidik dirinya sendiri agar bersedia mendidik anggota masyarakat lainnya.

\section{Manfaat Kemajuan Masjid Bagi Masyarakat}

a. Imaniyah

Umat Islam meyakini aqidah shahihnya bahwasannya tiada Tuhan selain Allah, yang Esa semata dan tiada sekutu bagi-Nya. Milik-Nya segala kerajaan dan pujan, dia menguasai secara mutlak segala sesuatu. Umat tersebut memiliki keyakinan yang benar dan terbatas dari segala macam segala bentuk kemusyrikan.

b. Ubudiyah

Umat menjelaskan sesuai Sunnah Rasulullah Saw, dan bersih dari segala macam bid'ah, dan menjalankan perintah agama sholat, puasa, zakat, haji dan ibadah lainnya yang benar sesuai tuntutan agama.

c. Adabul Muasyarah

Buah dari kemakmuran masjid lainnya adalah terlihat kerukunan dan keakraban serta saling menghormati dan memuliakan sesama muslim denagn saling mendahulukan hak-hak saudaranya daripada haknya sendiri.

d. Akhlak

Apabila masjid makmur maka akan terpancar dari lubuk hati sifat yang saling memaafkan, tawaddu' dan terhindar dari sifat-sifat tercela 
seperti: hasad, dendam, takabur, thamak, dan akhlakul karimah, yakni kebaikan akan dibalas dengan kebaikan, kebaikan dibalas dengan yang lebih baik lagi, dan perilaku buruk dibalas kebaikan mennyeliputi Islami.

Setiap amal yang baik pasti ada nilai kutamaan atau manfaat yang telah ditetapkan oleh Allah SWT dan Rasul-Nya. Keutamaan yang sedemikian besar memotivasi kaum Muslimin untuk selalu melaksanakan kebaikan itu, begitu pula bila memakmurkan masjid sehingga menjadi penting untuk dipahami nilai keutamaannya.

Dengan keutamaan yang sedemikian besar dan mulia, seharusnya semakin termotivasi untuk memakmurkan dan memiliki tanggungjawab yang lebih besar serta untuk selalu memakmurkan masjid karena dengan memakmurkannya maka akan memeperoleh IImu, pahala, dan keutamaankeutamaan yang dijanjikan.

\section{Peran Masjid}

Sejarah penyebaran Islam sangat erat kaitannya dengan perkembangan masjid, karena setiap kali Islam masuk ke berbagai negeri pastilah membangun masjid sebagai salah satu sarana dakwah dan berbagai kepentingan lainnya (Sucipto, 2000). Masa untuk mengetahui betapa besar peran dan fungsi masjid dalam dakwah, pendidikan dan penyebaran Islam, maka perlu dilihat kembali pada zaman Rasulullah, dimana beliau adalah teladan dan orang yang pertama kali mendirikan masjid sebagai basis segala aktivitas, mulai dari hubungan vartikal kepada Allah maupun horizontal kepada sesama manusia.

Berikut ini adalah 10 fungsi dan peranan yang telah diemban oleh masjid pada masa Rasulullah SAW: (Sucipto, 2000), 1). Tempat iabadah (shalat, dzikir). 2). Tempat konsultasi dan komunikasi (masalah ekonomi, sosial, dan budaya). 3). Tempat pendidikan. 4). Tempat santunan sosial. 5). Tempat latihan militer dan persiapan perang. 6). Tempat pengobatan para korban perang. 7). Tempat pengadilan dan pendamaian sengketa. 8). Aula 
dan tempat penerima tamu kenegaraan. 9). Tempat menahan tawanan. 10). Dan pusat penerangan, informasi dan pembelaan.

Kemudian fungsi masjid mulai berubah pada masa khalifah Umar bin Khattab, yang membangun fasilitas di dekat masjid, agar fungsi masjid difokuskan kepada kegiatan yang bermakna ukhrawi (Sucipto, 2000).

\section{Masjid Kampus dan Pengelolaannya.}

Keberadaan lembaga yang mengatur kegiatan masjid kampus baik bentuk yayasan maupun langsung di bawah pengawasan universitas merupakan bentuk keseriusan dalam memakmurkan dan meningkatkan peran masjid bagi warga kampus dan masyarakat pada umumnya. Seiring waktu peran dari lembaga masjid semakin vital, mengingat kebutuhan jamaah akan ilmu keagamaan makin tumbuh dan berkembang serta permasalahan umat yang makin komplit. Tak jarang masjid yang manajemennya kurang baik dan penawaran program kegiatan yang kurang menarik akan ditinggal oleh jamaah.

Menurut AF. Djunaidi dkk, empat masjid kampus di Indonesia bisa dijadikan contoh sebagai masjid yang menunjang bagi mahasiswa dalam menuntut ilmu, baik ilmu umum maupun ilmu agama. Empat masjid kampus di yogyakarta yaitu, masjid Kampus UGM, masjid UIN SUKA, masjid Ulil Albab UII, dan masjid Al-Mujahidin UNY, masing-masing masjid kampus memiliki program rutin dan unggulan. Kajian rutin masjid UGM yaitu, ahad pagi dan sore, materi tafsir. Selanjutnya hari rabu minggu pertama dan ketiga materinya tafsir. Sedangkan kamis sore, kajian menjelang buka puasa materinya lebih kontemporer. Sedangkan kegiatan-kegiatan luar masjid yang mengurusi dan mengerjakan program dari UKM Jamaah Shalahudin (JS) dan JS tidak dibawah takmir. Namun, JS ada koordinasi dengan takmir karena sama-sama bertujuan memakmurkan masjid. Sementara kajian Akbar kebanyakan digunakan oleh pihak luar, seperti kajian Uts Firanda Andirja dan $\mathrm{KH}$ AaGym yang didatangkan oleh Dompet Peduli Umat dan Tauhid (DPUD). Penggunaan masjid kampus UGM boleh dari kelompok 
mana saja asal tidak ada kegiatan di masjid, yang penting pas jadwalnya dan dalam koridor Qur'an dan Sunnah.

Terkait masjid kampus, Qodir Zuly dkk, mengatakan Optomalisasi fungsi seperti inilah yang terjadi di masjid-masjid kampus yang dari sisi kualitas sumberdaya jamaahnya relatif lebih maju. Masjid kampus umumnya dikelola melalui manajemen yang lebih baik dibandingkan masjid-masjid pada umumnya. Hal ini karena para aktifis adalah warga kampus dengan konsentrasi yang belum terbagi (Zuly, 2010).

\section{Masjid Kampus dan Penguatan Ideologi Islam}

Masjid kampus memiliki peran strategis dalam membangun dan membentuk karakter mahasisiwa. Dengan adanya masjid kampus diharapkan mahasiswa dapat memanfaatkanya sebagai sarana pengembangan kompetensi diri, memupuk dan memperkuat karakter diri melalui kajian-kajian keagamaan Islam, peribadatan maupun sebagai pusat syiar Islam kepada masyarakat luas.

Azyumardi Azra membagi corak berpikir mahasiswa kedalam tiga kelompok: pertama, yang merupakan kelompok mayoritas "common" muslim, yakni mahasiswa muslim yang mengamalkan ajaran Islam seadanya serta cenderung tradisional dan konvensional. Kedua, para mahasiswa yang berlatar belakang keagamaan sangat kuat dan mereka merasa perlu mengembangkan dirinya yang dalam konteks keagamaan adalah untuk lebih meningkatkan pemahaman mereka tentang Islam, dan dalam konteks akademis adalah untuk meningkatkan kemampuan berorganisasi dan keterampilan ilmiah. Dimasa lalu kelompok mahasiswa demikian cenderung memilih bergabung dengan organisasi kemahasiswaan Islam, terutama Himpunan Mahasiswa Islam (HMI), Pergerakan Mahasiswa Islam Indonesia (PMII), Ikatan Mahasiswa Muhammadiyah (IMM). Ketiga yakni kelompok mahasiswa yang lebih berorientasi kepada pengamalan Islam secara menyeluruh, kaffah. Kelompok-kelompok mahasiswa ini, apa karena pengaruh gerakan organisasi internasional Islam Ihwanul Muslimin (Mesir), Jama'at Islami (Pakistan), dan organisasi-organisasi Islam lainnya, atau 
sebagai hasil kreasi para mahasiswa Islam Indonesia, mereka mengadakan kajian-kajian Islam secara intensif dalam bentuk usrah-usrah. Kelomok mahasiswa Islam ini pula yang kemudian mendirikan kegiatan mentoring atau tutorial keagamaan di masjid-masjid kampus, termasuk pesantren kilat bagi para pelajar SD, SLTP, dan SLTA (Azyumardi, 2002).

Menurut Mohammad Nuh sedikitnya ada tiga peran masjid dalam sebuah perguruan tinggi. Pertama, pencipta atsmofir kesejukan. Kalau atsmofir sejuk tanaman akan tumbuh dengan baik. Benik-benih kemuliaan akan tumbuh subur. Kedua, masjid kampus harus terlibat dalam proses menanam dan menyamai benih-benih kemuliaan. Masjid kampus dapat berperan serta mulai dari hal-hal sederhana seperti bimbingan awal akademik, terlibat dalam hal Pendidikan keagamaan dan hal lainnya. Ketiga. Yang tidak kalah pentingnya adalah ikut mencari benih kebaikan (Junaidi, 2010).

Masjid dapat berfungsi ideal jika dikelola secara ideal pula. Dan masjid kampus memiliki peluang yang lebih besar untuk menghimpun para jama`ah yang siap mengelola secara ideal. Mereka pada umumnya memiliki idealisme dan waktu yang relative bebas. Namun, memang ada kesan ekslusif yang melekat pada sebagian aktivitas masjid kampus. Akan tetapi, jika ditelesuri akar pertumbuhannya, eksklusifisme itu sebetulnya menjadi sebuah keniscayaan sebagai implikasi proses sosial yang dilalui. Interaksi diantara aktivis masjid kampus relativ intensif. Karena itu, kegiatan apapun yang mereka lakukan hampir selalu berlangsung hingga proses internalisasi. Proses internalisasi inilah yang memungkinkan dapat membentuk watak atau keperibadian yang revolusioner sehingga terkesan eksklusif.

Para aktivis masjid kampus umumnya berlatar belakang yang berbeda-beda, ada yang memiliki latar pendidikan agama yang kuat, seperti para santri dari pasantren-pasantren atau siswa madrasah. Tetapi ada pula diantaranya yang mungkin baru mengenal Islam ketika mereka mulai berintraksi di kampus. Jika keberagamaan para aktivis masjid kampus yang 
bergerak di antara dua corak pemahaman keagamaan ini juga akan membentuk dinamika sosil yang tidak biasa.

\section{Nilai Budaya Dalam Simbol}

Seorang filsuf berkebangsaan Jerman Ernst Cassier menyebutkan bahwa "manusia adalah makhluk penyimbol (homo symbolicum)." (McLaughlin, 1990). Kalimat ini mungkin tidak terlalu salah karena dalam peradaban umat manusia telah banyak tersebar banyak simbol yang diciptakan dengan menyimpan banyak makna dan maksud tertentu yang sarat dengan kultur budaya lokal. Dalam peradaban budaya Jawa baik Hindu, Budha maupun Islam bangunan-bangunan rumah tempat tinggal maupun tempat ibadah menyimpan makna yang sangat penting untuk dipahami. Hal ini sependapat dengan Indal Abror simbol apapun akan tidak bermanfaat (useless) dan hanya menjadi peninggalan material biasa jika makna dari simbol tersebut tidak dipahami (Obror, 2016).

Dalam pemaknaan simbol terbagi menjadi dua macam yaitu simbol konotatif dan simbol denotative (Susanne, 1997). Simbol dapat bersifat konotatif ketika makna suatu simbol itu hanya diketahui atau dipahami oleh orang perorang, sedangkan simbol yang bersifat denotatif yaitu ketika simbol yang diciptakan dapat diketahui maknanya secara sosial atau dapat diketahui oleh banyak orang. Pemahaman terhadap makna simbol dalam ranah akademik akan sangat bermanfaat dan dapat memberi efek positif bagi mereka yang memahami.

Simbol akan memberi manfaat yang besar untuk sebuah lingkungan sosial jika sebuah simbol dapat berfungsi secara denotatif karena simbol memiliki peran sosial seperti menjadi jembatan untuk transmisi kebudayaan, sebagai pelestari keutuhan kelompok, dapat mendorong keharmonisan serta mencegah perpecahan sosial, juga dapat menjaga agar cita-cita ideal masyarakat tetap berspirit dan tidak kabur, sehingga secara makna denotatif akan memiliki makna dan memberi manfaat sangat penting bagi generasi penerus. 
Apabila makna fungsi simbol tersebut mengalami pergeseran yang seharusnya simbol bermakna denotatif bergeser ke konotatif, maka makna simbol hanya bermanfaat secara pribadi-pribadi atau hanya beberapa orang saja. Bisa jadi, jika makna simbol hanya diketahui oleh tokoh-tokoh tertentu dan apabila orang yang mengetahui makna simbol tersebut meninggal, maka makna simbol itupun ikut akan hilang.

Ada sebab-sebab tertentu sehingga terjagi pergeseran makna simbol suatu benda atau bangunan. Sebuah makna simbol bisa kehilangan makna jika tidak ada community of speaker, jika sebuah simbol tidak lagi disampaikan atau disebut-sebut oleh masyarakat, maka makna simbol tersebut bisa kehilangan makna sebenarnya.

\section{METODE PENELITIAN}

\section{a. Tipe dan Pendekatan Penelitian}

Penelitian ini menggunakan pendekatan kualitatif yang pada prinsipnya ingin memberikan, menerangkan, mendeskripsikan secara kritis, atau menggambarkan suatu fenomena, suatu kejadian, atau suatu peristiwa interaksi sosial dalam masyarakat untuk mencari dan menemukan makna (meaning) dalam konteks yang sesungguhnya (natural setting) (Yusuf, 2014). Penelitian ini juga memilih tipe studi kasus (Case Studies) yakni suatu proses pengumpulan data dan informasi secara mendalam, mendetail, intensif, holistik, dan sistematis tentang orang, kejadian, social setting (latar sosial, atau kelompok dengan menggunakan berbagai metode dan teknik serta banyak sumber informasi untuk memahami secara efektif bagaimana orang, kejadian, latar alami (social setting) itu beroperasi atau berfungsi sesuai konteksnya. (Yusuf, 2014).

Kemudian dalam penelitian ini peneliti akan menggunakan dua pendekatan. Pertama pendekatan historis untuk mengungkap kronologis, keberadaan, pertumbuhan dan perkembangan masjid Amalbakti Muslim Pancasila. Yulis menjelaskan bahwa historical aproach is the studi of the past and historical data can be used to understand present social problems 
(Yulian, 1989). Artinya pendekatan sejarah studi tentang masa lampau dan data-data sejarah yang dapat digunakan untuk memahami masalah-masalah sosial sekarang. Dengan mengetahui sejarah, maka dapat membantu peneliti dalam menganalisis perkembangan masjid Yayasan Amalbakti Muslim Pancasila.

Pendekatan kedua yaitu pendekatan fenomenologis guna mengungkap dan menggali kegiatan-kegiatan apa saja yang pernah dilakukan Yayasan Amalbakti Muslim Pancasila, serta menggali makna simbol-simbol masjid di masjid Yayasan Amalbakti Muslim Pancasila. Masjid Yayasan Amalbakti Muslim Pancasila dijadikan sebagai objek penelitian, dengan menggunakan masjid sebagai pusat kegiatan masyarakat, baik kegiatan keagamaan maupun kegiatan kemasyarakatan.

\section{b. Lokasi Penelitian}

Lokasi yang dijadikan sampel area dalam penelitian ini adalah Kecamatan Sirimau, dan Teluk Ambon yang kesemuanya masih masuk dalam wilayah kota Ambon Provinsi Maluku. Karena di dua kecamatan inilah terdapat 4 (empat) buah masjid Yayasan Amalbakti Muslim Pancasila dan berada pada lokasi pendidikan yaitu di kampus IAIN Ambon, Kampus UNPATTI, Perumahan Wayame, dan Kampung Tihu Perumnas Poka.

\section{c. Subjek Penelitian}

Adapun informan atau subyek penelitian dalam penelitian kualitatif berkembang terus atau menggelinding (snowball) secara berkelanjutan sampai data yang dikumpulkan dianggap memuaskan atau jenuh (redundancy) Gunawan, 2016).

Subjek dalam penelitian ini adalah orang-orang yang mengetahui, berkaitan atau menjadi ta'mir masjid YAMP di Kota Ambon. Mereka diharapkan dapat memberikan informasi dan gambaran terperinci tentang perkembangan masjid YAMP di Kota Ambon. Setelah dilakukan studi pendahuluan, selanjutnya ditetapkanlah beberapa pihak yang menjadi subjek dalam penelitian ini yang merupakan informan kunci dan informan biasa. 
Untuk keperluan penelitian ini, yang menjadi responden atau sampling meliputi :1). Pengurus/Ta'mir Masjid YAMP. 2). Tokoh Agama atau Tokoh Masyarakat yang mengetahui perkembangan masjid YAMP. 3). Jamaah atau masyarakat sekiat masjid yang dianggap memiliki informasi tentang masjid YAMP.

\section{d. Sumber Data Penelitian}

Sumber data dalam penelitian ini ada dua yaitu sebagai berikut: 1). Data Primer yaitu data yang berhasil dikumpulkan sendiri oleh peneliti dari sumber-sumber yang pertama. Dalam penelitian ini, peneliti memperoleh data melalui observasi dan wawancara, yang terkait dengan informasi yang peneliti butuhkan untuk penelitian ini. Data primer adalah data yang diperoleh untuk hasil wawancara secara langsung. 2). Data Sekunder yaitu data yang disusun dalam bentuk dokumen-dokumen, misal data mengenai penglihatan secara langsung keadaan di masjid Yayasan Amalbakti Muslim Pancasila.

\section{e. Teknik Pengumpulan Data}

Teknik pengumpulan data dilakukan langsung terhadap sumber data penelitian, diantaranya: ta'mir masjid, tokoh agama atau tokoh masyarakat, jamaah atau warga sekitar tempat dilakukannya penelitian melalui teknik observasi dengan menggunakan lembar observasi sebagai pedoman instrumennya. Disamping itu juga dilakukan melalui penyebaran angket untuk mencari data-data tentang kondisi dan inventaris masjid. Selanjutnya, dalam penelitian ini juga dilakukan wawancara dengan menggunakan pedoman wawancara sebagai instrumennya. Kemudian pengumpulan data dengan melalui dokumentasi adalah pengumpulan dan identifikasi data dan informasi yang ada pada sumber data, yang dianggap dapat menjawab pertanyaan-pertanyaan penelitian.

Suharsimi Arikuto mengemukakan bahwa penentuan metode atau cara (pendekatan) melakukan penelitian ini akan sangat menentukan apa variabel atau objek penelitian yang akan ditatap, dan sekaligus menentukan subjek penelitian atau sumber dimana kita akan memperoleh data (Arikonto, 2006). Kegiatan pengumpulan data dalam penelitian ini dapat ditempuh 
dengan berbagai aktivitas yaitu diawali dengan mengobservasi secara langsung keadaan aktivitas informan di lokasi penelitian secara riil, kemudian dilanjutkan dengan beberapa aktivitas pengumpulan data.

Teknik pengumpulan data yang digunakan dalam penelitian ini terdiri dari:

Observasi adalah kegiatan menggunakan pemusatan perhatian terhadap suatu objek dengan menggunkan alat indera. Jadi observasi dapat dilakukan melalui penglihatan dan pendengaran. Metode ini digunakan untuk memperoleh data yang berkaitan dengan kegiatan-kegiatan yang dilakukan masjid Yayasan Amalbakti Muslim Pancasila Kota Ambon

Wawancara (interview) adalah sebuah dialog yang dilakukan untuk memperoleh informasi dari informan. Metode ini digunakan untuk memperoleh data dari bapak Ta'mir masjid, tokoh masyarakat dan orangorang yang pernah terlibat dalam kegiatan masjid Yayasan Amalbakti Muslim Pancasila Kota Ambon.

Teknik dokumentasi digunakan untuk pengumpulan data dengan menghimpun dan menganalisis dokumen-dokumen masjid masjid Yayasan Amhalbhakti Muslim Pancasila Kota Ambon.

\section{f. Analisis Data}

Data mentah yang telah didapatkan melalui observasi, wawancara, dan dokumentasi dilakukan pereduksian data. Selanjutnya dideskripsikan dalam bentuk kategori. Data yang didapatkan akan dianalisis dan disajikan dalam bentuk narasi. Teknik analisis data yang dilakukan dalam penelitian ini adalah analisis data kualitatif, mengikuti konsep yang dikembangkan oleh Miles dan Huberman, yaitu sebagai berikut:

Reduksi data merupakan suatu proses menajamkan, memfokuskan, memusatkan perhatian dan menyedehanakan data yang diperoleh dari observasi, wawancara, dan dokumentasi.

Penyajian data merupakan suatu proses penyajian data secara terorganisir dan terstruktur dari reduksi data sehingga memungkinkan peneliti dapat menarik kesimpulan. 
Merupakan suatu proses yang didasarkan pada data yang telah diperoleh dalam reduksi data dan penyajian data kemudian dirangkum dan dibuat kesimpulan (Sugiyono, 2005).

\section{g. Pengecekan Keabsahan Data}

Keabsahan data mutlak diperlukan dalam penelitian kualitatif. Oleh karena itu, dilakukan pengecekan keabsahan data salah satunya menggunakan trianggulasi. Dalam hal triangulasi, Stainback dalam Sugiyono menyatakan bahwa "the aim is not determine the truth about some social phenomenom, rather the purpose of triangulation is to increase one's understanding of what ever is being investigated". Tujuan dari triangulasi bukan untuk mencari kebenaran tentang beberapa fenomena, tetapi lebih pada peningkatan pemahaman peneliti terhadap apa yang telah ditemukan (Sugiyono, 2009).

Dalam melakukan pengecekan data, peneliti menerapkan teknik sebagai berikut: 1). Triangulasi, triangulasi ini merupakan cara yang paling umum digunakan bagi peningkatan validitas data dalam penelitian kualitatif. 2). Memperpanjang keikutsertakan, seperti yang telah dikemukakan bahwa dalam penelitian kualitatif, peneliti merupakan instrumen kunci, maka keikutsertaan peneliti sangat menentukan dalam pengumpulan data. Agar data yang diperoleh sesuai dengan kebutuhan pengamatan dan wawancara tentunya tidak dilakukan dengan waktu yang sangat singkat, tetapi memerlukan perpanjangan keikutsertakan dalam penelitian. 3). Ketekunan pengamatan, ketekunan pengamatan bermaksud menentukan ciri-ciri dan unsur-unsur dalam situasi sangat relevan dengan persoalan atau isu yang sedang dicari dan kemudian memusatkan diri pada hal-hal tersebut secara rinci.

\section{HASIL DAN PEMBAHASAN}

\section{Analisis Kontribusi Masjid Yayasan Amalbakti Muslim Pancasila}

Pembangunan masjid Yayasan Amalbakti Muslim Pancasila jika di lihat dari tanggal peresmian ternyata berbeda-beda, masjid muhajirin adalah yang paling tua bila dibandingkan dengan tiga masjid lainnya yaitu 
diresmikan pada tahun 1986, artinya jika dihitung usia masjid hingga tahun 2020 ini berarti masjid muhajirin ini telah berusia 34 tahun. Jika dikaitkan dengan waktu dibentuknya Yayasan Amhalbhakti Muslim Pancasila yaitu tahun 1982, maka selang waktu yang tidak lama pembangunan masjid muhajirin telah masuk di Ambon. Pembangunan masjid Muhajirin ini bisa jadi di mulai di tahun-tahun sebelumnya entah 1 atau 2 tahun sebelumnya karena untuk membangun sebuah bangunan besar pasti membutuhkan waktu yang relatif panjang.

Menyusul 3 masjid berikutnya yaitu masjid Imam Rijali IAIN Ambon yang diresmikan pada tahun 1996, masjid Gemilaha Majirah Kampus UNPATTI, dan masjid Daarun Naim Wayame tahun 1998. Sesuai informasi dari narasumber bahwa ketiga masjid ini dalam pengajuan proposal bersamaan waktu itu, bisa jadi waktu pembangunannya pun bersamaan, akan tetapi berbeda pada waktu peresmiannya. Sebagaimana yang disampaikan Hasan Pattikupang bahwa pada saat dibangun masjid Imam Rijali Kampus IAIN Ambon, pembangunan masjid di Gemilaha Majirah Kampus UNPATTI dan masjid Daarun Naim juga sedang dalam pengerjaan. Diperkuat informasi dari Imam Musonep, beliau menceritakan bahwa pengajuan proposal masjid pada saat itu di wakili bapak Waskito bahwa ada 3 proposal yang diajukan kepada Yayasan Amalbakti Muslim Pancasila. Kedua informasi ini dapat dijadikan dasar pegangan bahwa memang pembangunan dan pengajuan untuk mendapatkan bantuan berupa bangunan masjid ini dilakukan secara bersamaan dan proses pembangunannya pun bersamaan, hanya dalam proses peresmiannya yang berbeda-beda.

Kini masjid-masjid peninggalan Yayasan Amalbakti Muslim Pancasila ini telah mulai mengadakan perbaikan dan pelebaran, serta telah berkembang sesuai tuntutan zaman. Masjid Muhajirin Kampung Tihu Desa Poka adalah masjid yang pertama di bangun adalah masjid yang mula-mula membangun Madrasah Aliyah (MA) yang di bangun di samping kiri masjid, namun akibat kerusuhan Ambon tahun 1999 bangunan ini hancur terbakar 
bersamaan dengan bangunan masjidnya. Tempat wudhu dan toilet sudah dipindahkan ke belakang dengan dibuatkan bangunan sendiri dan agak terpisah dari masjid, sedangkan bekas tempat wudhu di sebelah kanan di rubah dan dialihfungsikan sebagai sekretariat TPQ. Kusen pintu dan jendela yang terbakar telah di ganti dengan yang baru, akan tetapi bentuk ukirannya masih seperti yang aslinya. Daun pintu yang dulu berasal dari kawat besi, kini sudah di ganti dengan daun pintu dari kayu.

Masjid Imam Rijali IAIN Ambon juga berusaha memperluas halaman dengan menambahkan teras depan agar lebih luas dan dapat menampung jamaah lebih banyak. Teras yang cukup luas ini ternyata sangat multifungsi, selain dapat menampung jamaah shalat jum'at yang semakin meningkat juga berfungsi untuk kegiatan-kegiatan yang lain seperti kegiatan perkuliahan, kajian-kajian yang dilakukan UKM, diskusi mahasiswa maupun dosen, pelatihan-pelatihan kepemimpinan, kegiatan Darmawanita, kegiatan Ma'had al-Jamiah dan masih banyak lagi, sehingga manfaat dari pelebaran teras masjid ini sangat berguna dan bermanfaat.

Masjid Gemilaha Majirah Kampus UNPATTI pun telah berbenah dengan mengganti plafon ruang utama dengan plafon yang lebih baik, tempat wudhu pun juga telah diperbaiki dan lebih bersih sehingga membuat nyaman para pengunjung, pelabaran teras juga sudah berdiri. Perbaikan ini dilakukan tidak lain adalah untuk memberikan rasa nyaman kepada pengguna terutama mahasiswa dan dosen untuk kegiatan-kegiatan keagamaan maupun kegiatan-kegiatan kependidikan. Hampir semua mahasiswa maupun dosen yang muslim, UKM, dari semua fakultas memanfaatkan masjid untuk kegiatan-kegiatan tersebut, sehingga pelabaran masjid menjadi sebuah kebutuhan utama saat ini.

Begitupun masjid Daarun Naim Wayame justru lebih bagus lagi dalam perbaikan bangunannya baik yang di dalam maupun yang di luar, toilet dan wc terjaga kebersihannya, teras luas, dan memiliki kantor sekretarian yang sangat baik. Masjid Daarun Naim memiliki majlis ta'lim yang cukup aktif seperti halnya masjid Muhajirin, kegiatan TPQ, PAUD/RA, dan MI yang 
masih aktif, serta satu-satunya masjid Yayasan Amalbakti Muslim Pancasila yang memiliki menara pengeras suara.

Jika dilihat dari tabel di atas terlihat dapat dianalisis bahwa hanya 2 masjid yang memiliki Taman Pengajian Al-Qur'an (TPQ) 1 masjid yang memiliki MI/SD, 1 masjid yang memiliki MTs./SMP, 1 masjid yang memiliki kegiatan kemah santri, 2 masjid yang memiliki majlis ta'lim, semua masjid difungsikan oleh mahasiswa, 3 masjid yang mengadakan kegiatan latihan penyelenggaraan jenazah, 3 masjid yang difungsikan untuk tempat pernikahan, 3 masjid yang pernah digunakan untuk kegiatan MTQ, semua masjid digunakan untuk kegiatan menyemarakkan idhul fitri dan idhul adha dilanjutkan dengan pemotongan hewan kurban, 2 masjid yang melakukan kegiatan pelatihan khatib dan imam, 1 masjid yang mengadakan kegiatan kultum sebelum dzuhur, dan 2 masjid yang mengadakan kegiatan PHBI.

Masjid yang memiliki TPQ, PAUD/RA dan MTs/SMP didominasi oleh masjid-masjid yang berada di luar kampus dan yang memiliki majlis ta'lim pun hanyalah masjid di luar kampus. Pengguna masjid lebih banyak masyarakt sekitar karena lingkungan ini di dominasi masyarakat umum. Berbeda dengan masjid yang di dalam kampus kegiatan-kegiatan yang dilakukan adalah lebih banyak kegiatan-kegiatan akademis dan bermacammacam kegiatannya. Kreatifitas mahasiswa dan dosen itulah yang menjadikan masjid semakin hidup.

\section{Analisis Tanggapan Masyarakat Tentang Keberadan Masjid YAMP}

Kredibilitas masjid hingga saat ini masih memiliki trust (kepercayaan) yang sangat tinggi sebagai lembaga sentral bagi kehidupan keagamaan di masyarakat. Hal ini dapat diberdayakan oleh Perguruan Tinggi sebagai pelaksana dari tri dharma perguruan tinggi yang meliputi aspek pendidikan, penelitian dan pengabdian, dan juga merupakan salah satu institusi yang memiliki peran dan fungsi sebagai pengembangan keislaman, dakwah dan peningkatan kesejahteraan masyarakat, dengan melalui model pengabdian masyarakat berbasis masjid diharapkan dapat memaksimalkan peran masjid sebagai penggerak sektor dimensi kehidupan baik dunia maupun akherat. 
Perubahan fungsi dan peran masjid ini terjadi karena adanya perubahan pada unsur teknologi dan budaya non matterial. Pada era modern teknologi berkembang sangat pesat sehingga dengan adanya perubahan teknologi seringkali menghasilkan kejutan budaya yang pada gilirannya akan memunculkan pola-pola perilaku yang baru. Maka dampaknya terhadap kehidupan sosial dan budaya kurang signifikan (Supardi, 2001). Memahami Masjid secara universal berarti juga memahaminya sebagai sebuah instrumen sosial masyarakat Islam yang tidak dapat dipisahkan darimasyarakat Islam itu sendiri. Keberadaan Masjid pada umumnya merupakan salah satu perwujudan aspirasi umat Islam sebagai tempat ibadah yang menduduki fungsi sentral. Mengingat fungsinya yang strategis, maka perlu dibina sebaik-baiknya, baik segi fisik bangunan maupun segi kegiatan pemakmurannya.

Menurut Ahmad Sutarmadi, Masjid bukan sekedar memililiki peran dan fungsi sebagai sarana peribadatan saja bagi jemaahnya. Mesjid memiliki misi yang lebih luas mencakup bidang pendidikan agama dan pengetahuan, bidang peningkatan hubungan sosial kemasyarakatan bagi para anggota jemaah, dan peningkatan ekonomi jemaah, sesuai dengan potensi lokal yang tersedia. Optimalisasi fungsi Masjid dalam kehidupan umat, tidak ditentukan oleh kemegahan bangunan Masjid semata. Banyak ditemukan Masjid yang besar, namun sepi jemaah dan minim kegiatan. Namun patut bersyukur sejak beberapa dekade terakhir cukup banyak yang aktif dengan berbagai kegiatan,seperti pengajian rutin, konsultasi agama dan keluarga, pemberdayaan ekonomi umat dan lain-lain. Untuk itu yang diperlukan seharusnya adalah mensikronkan pemberdayaan potensi Masjid dengan pemberdayaan potensi sosial dan pendidikan dan lainnya untuk kepentingan umat.

Olehnya itu hasil penelitian menunjukkan bahwa tanggapan warga tentang keberadaan masjid YAMP sangatlah beragam tergantung kondisi yang dialami oeh para warga tersebut namun keseluruhaanya mengatakan akan keberadaannya sangat membantu proses ibadah mereka sekaligus 
mendekatkan diri mereka terhadap Tuhan Yang Maha Esa itu lebih penting selain didalam masjid tersebut memiliki ketenangan dan kenyamanan dalam melakukan ibadah, disamping itu juga keberadaan masjid YAMP sangat dibutuhkan oleh para warga karena keberadaannya yang baik ibadah yang dilakukan juga terasa lurus dan rapat karena tidak adanya pembatas seperti di masjid-masjid yang lain yang memiliki tiang didalam mesjid yang menjadikan shaf sholat ada yang terputus. Selain itu juga masjid YAMP sangat baik desainnya karena dalam penyampaian khotbah maupun pengajian tidak dihalangi oleh oleh tiang sehingga jelas kelihatan yang mengkhotbah dan memberikan materi jika dilakukan di dalam masjid, selain itu juga ruang masjid terasa luas karena tidak ada tiang yang ada didalamnya.

Masjid sebagai salah satu pemenuh kebutuhan spiritual sebenarnya meskipun fungsi utamanya sebagai tempat menegakkan shalat, namun masjid bukanlah hanya tempat untuk melaksanakan shalat saja. Tetapi juga merupakan pusat kegiatan sosial kemasyarakatan dimasa rasululah SAW, selain dipergunakan untuk shalat, berdzikir dan beri'tikaf, masjid di pergunakan untuk kepentingan sosial. Misalnya, sebagai tempat belajar dan mengajarkan kebajikan (menuntut ilmu). Selain itu masjid juga berfungsi sebagai tempat sosial kemasyarakatan seperti silaturahmi untuk memperkuat persaudaraan, tempat menimba ilmu, tempat pengumpulan dana zakat, infaq dan sadakah, lembaga solidaritas dan bantuan kemanusiaan, dan tempat bergotong royong di dalam mewujudkan kesejahteraan bersama.

\section{Analisis Kontribusi Masjid YAMP dalam Pembangunan Masyarakat Muslim di Kota Ambon}

Masjid merupakan wadah yang strategis dalam membina dan menggerakkan potensi umat Islam untuk mewujudkan sumber daya manusia (SDM) yang tangguh dan berkualitas. Sebagai pusat pembinaan umat, eksistensi masjid kini dihadapkan pada berbagai perubahan dan tantangan yang terus bergulir di masyarakat. Isu globalisasi dan masyarakat informasi merupakan fenomena yang tidak dapat diabaikan begitu saja. Semakin 
dominannya sektor informasi dalam kehidupan masyarakat, tentu akan memberikan banyak implikasi termasuk peluang dan tantangan kepada umat Islam dalam bersosialisasi dan beraktualisasi di masyarakat luas.

Pengembangan sumber daya manusia melalui pemberdayaan ekonomi jemaahnya merupakan sebuah cita-cita besar tentang revitalisasi fungsi Masjid sebagai wadah pemberdayaan untuk kesejahteraan umat Islam. Cita-cita besar ini merupakan sesuatu yang sangat historis dan sesuai dengan konteksnya karena dalam Islam idealnya Masjid adalah pilar utama dalam pembinaan para jemaah dan tokoh-tokoh Islam, disamping pilar-pilar penting lainnya seperti pesantren menjadi tempat untuk pengkaderan ulama' dan kyai, perguruan tinggi Islam untuk membina para intelektual dan cendikiawan muslim, serta pengusaha yang menjadi pilar dalam membangun wirausahaan yang akan menopang bagi kebangkitan umat Islam di Indonesia dan dunia Islam pada umumnya. Namun, terpenting bagi pembentukan masyarakat Islam. Karena masyarakat muslim tidak akan terbentuk secara kokoh dan rapi kecuali dengan adanya komitmen terhadap sistem, akidah dan tatanan Islam. Hal ini tidak akan dapat dimunculkan kecuali dari Masjid.

Masjid merupakan simbol dari agama yang bisa menjadi Transformative capacity agama Islam, seperti yang telah jelas terdapat dalam buku sejarah Islam, baik secara sosial, politik maupun budaya. Maka dalam hal ini masjid berfungsi untuk melangsungkan berbagai macam aktivitas, meskipun secara umum masjid digunakan sebagai tempat untuk beribadah. Keberadaan masjid akan selalu menjadi sebuah simbol, dan merupakan tempat untuk melakukan berbagai aktivitas salah satunya yaitu peribadahan.

Masjid merupakan pranata keagamaan yang tidak terpisahkan dari kehidupan spiritual, sosial, dan kultural umat. Dimana ada umat Islam pasti di situ ada masjid, masjid juga merupakan simbol keislaman, jika ada masjid maka di situpun disinyalir ada kehidupan umat Islam. Masjid memiliki peran yang cukup besar bagi masyarakat, bukan hanya sebagai tempat ibadah, melainkan juga sebagai pusat peradaban bagi umat Islam. Selain itu, masih 
banyak kontribusi masjid dalam pemberdayaan umat Islam, baik secara individu, sosial maupun dalam kehidupan berbangsa dan bernegara.

Diantara salah satu kontribusi masjid YAMP dalam pembangunan masyarakat Muslim di kota Ambon adalah sebagai pusat kegiatan pendidikan dan layanan sosial, seperti kajian-kajian ilmu yang dilakukan di masjid oleh pengurus masjid ataupun LDK. Sedangkan pada layanan sosial seperti buka puasa bersama, pengembelihan hewan kurban, dan musyawarah dengan warga. Keberadaan masjid haruslah dioptimalkan peran dan fungsinya, sehingga kegiatan yang berlangsung seperti perekonomian dapat bertahan dan berlangsung sesuai dengan yang direncanakan. Selain itu pengelolaan masjid bertujuan agar masyarakat memiliki pemberdayaan diri, dan keberadaan masjid dapat memberikan manfaat terhadap kehidupan masyarakat.

Lembaga Dakwah Kampus Al-'Izzah IAIN Ambon adalah organisasi intra kampus yang menjadi tumpuan dan harapan bagi kampus dalam membantu pembentukan akhlak mahasiswa. Bentuk pembinaan yang tidak monoton menjadi daya tarik tersendiri dan menjadi program unggulan organisasi dalam penanaman nilai-nilai keislaman, keilmuan serta sosial kemunusiaan. Aktifitas LDK yang bersifat keislaman mampu memberikan penyadaran akhlak mulia dan dapat memberi pengaruh terhadap perilaku mahasiswa dalam aktifitas kehidupannya. (Khozin, 2018. hlm. 52-63).

Kontribusi masjid dalam pembangunan masyarakat ini sangat perlu karena masjid bukan hanya sebagai tempat ibadah semata namun juga bagaimana menjadikan sebagai icon perkembangan agama, maka perlu adanya peran masjid dalam membangun masyarakat yang agamamis, berpendidikan, serta mampu bagaimana menjadikan masjid sebagai layanan sosial untuk menjadikan masjid sebagai peran utama dalam membangun peradaban. Sebuah perspektif baru dalam memahami peran masjid, masjid tidak lagi dipahami sebagai instrumen pasif layaknya sebuah gedung, bangunan atau tempat melainkan sebagai suatu organisme hidup atau instrument aktif yang mampu memotivasi, menggerakkan lingkungannya 
untuk berkembang ke arah yang lebih baik, maka secara luas masjid berubah menjadi lambang kebesaran Islam, pusat pengembangan ilmu sehingga memotivasi lingkungan atau jama'ahnya untuk berdaya dan sadar akan pentingnya pendidikan, perekonomian, kegiatan sosial, budaya sampai politik, sebagai eksistensi masyarakat itu sendiri.

Pengembangan sumber daya manusia melalui pemberdayaan ekonomi masjid merupakan sebuah cita-cita besar tentang revitalisasi fungsi Masjid sebagai wadah pemberdayaan untuk kesejahteraan umat Islam. Citacita besar ini merupakan sesuatu yang sangat historis dan sesuai dengan konteksnya karena dalam Islam idealnya masjid adalah pilar utama dalam pembinaan para jemaah dan tokoh-tokoh Islam. Namun, terpenting bagi pembentukan masyarakat Islam. Karena masyarakat muslim tidak akan terbentuk secara kokoh dan rapi kecuali dengan adanya komitmen terhadap sistem, akidah dan tatanan Islam. Hal ini tidak akan dapat dimunculkan kecuali dari Masjid.

\section{PENUTUP}

Sejarah Masjid YAMP yang berada di Provinsi Maluku terdapat 6 buah masjid. Keberadaanya 4 buah di Kota Ambon yaitu 1 buah di Kampus IAIN Ambon, 1 buah di Kampus UNPATTI, 1 buah di Kelurahan Tihu/Perumnas Poka, dan 1 buah di BTN Wayame. Sedangkan 1 masjid lagi berada di Kabupaten Maluku Tenggara tepatnya di samping RSUD Kota Tual, 1 masjid lagi diberada di Banda Naira Tanah Rata yang didirikan pertama kali pada tahun 1986. Serta Model memakmurkan masjid YAMP oleh takmir masjid atau masyarakat sekitar selain ibadah, dilakukannya kajian-kajian, diskusidiskusi dan juga kegiatan-kegiatan sosial yang berguna untuk masyarakat serta jamaah masjid masjid YAMP di kota Ambon.

Tanggapan masyarakat tentang keberadaan masjid YAMP adalah sangat dibutuhkan karena keberadaannya yang baik, dan sangat membantu proses ibadah sekaligus mendekatkan diri mereka terhadap Tuhan Yang Maha Esa. Selain itu masjid tersebut memiliki ketenangan dan kenyamanan dalam melakukan ibadah kaena tidak ada pembatas. Selain itu juga masjid 
YAMP sangat baik desainnya karena dalam penyampaian khotbah maupun pengajian tidak dihalangi oleh tiang sehingga jelas kelihatan yang mengkhotbah dan yang memberikan materi.

Kontribusi masjid YAMP dalam pembangunan masyarakat Muslim di kota Ambon sangat baik hal ini bisa dilihat dari kajian-kajian rutin yang dilaksanakan baik pengurus masjid maupun majelis ta'lim baik itu kajian rutin, buka puasa bersama, memotong hewan qurban, membantu mahasiswa untuk tinggal di masjid, dan diskusi-diskusi keagamaan yang lain dalam membangun negara kedepan dengan baik.

\section{DAFTAR PUSTAKA}

[1] Aboebakar, Sedjarah Masjid dan Ibadah di Dalamnya Djakarta: N. V. Visser, 2013.

[2] Abror, Indal. Aktualisasi Nilai-Nilai Budaya Masjid Pathok Negoro, Jurnal ESENSIA Vol 17, No. 1, April 2016.

[3] Al Munawar, Said Agil Husein. Sambutan Menteri Agama Republik Indonesia. Dalam Buku Pedoman Manajemen Masjid.

[4] Ali, Mukti. Beberapa Persoalan Agama Dewasa Ini, Jakarta Rajawali Pers, 1987.

[5] An-Nahlawi, Abdurrahman. Ushulut Tarbiyah Al-Islam Wa Asalibuha, Beirut: Darul Fikr, 1979.

[6] Arikunto, Suharsimi. Prosedur Penelitian Suatu Pendekatan Praktik (Jakarta: Rineka Cipta, 2006.

[7] Ayyub, Moh. E. Manajemen Masjid Jakarta: Gema Insani Press, 1998.

[8] Azra, Azyumardi. Kelompok "Sempalan" di Kalangan Mahasiswa PTU: Anatomi Sosio-Historis, dalam Fuaduddin \& Cik Hasan Bisri, (ed), Dinamika Pemikiran Islam di Perguruan Tinggi, Ciputat: Logos, 2002. 
[9] Bakar, Abu. Sejarah Masjid Dan Amal Ibadah Dalam Islam Jakarta Fa. Adil.

[10] Bani, Sudin. Kontribusi Pesantren dalam Sistem Pendidikan Nasional Auladuna, Vol. 2 No. 2 Desember 2015: 264-273 Fakultas Tarbiyah dan Keguruan UIN Alauddin Makassar Jl. Sultan Alauddin No. 36 Samata Gowa.

[11] Bhakti, N. Yudi. Pengertian Kontribusi (diakses dari 2012 http:// artikel terkait, eprints.uny.ac.id/8957/3/BAB\%202-08502241019.Pdf.

[12] Cholid, Nur. Kontribusi Filsafat Pragmatisme Terhadap Pendidikan Magistra Jurnal IImu Pendidikan Dasar dan Keislaman Volume 4., No. 1 Maret 2013 FAI Unwahas Semarang.

[13] Dahlan, Abdul Aziz et. Al., Ensiklopedi Hukum Islam. Jilid 6, Cet. I; Jakarta: Ichtiar Baru Van Hoeve, 1996.

[14] Depertemen Agama RI, Al-Qur'an Dan Terjemahanya, Depok: Cahaya Qur'an 2011.

[15] Dikuti dari http://a-research.upi.edu/operator/upload/bab_ii(12).pdf dalam Anne Ahira, Terminologi Kosa Kata, Jakarta: Aksara, 2012.

[16] Djunaidi, AF. Lukman A. Irfan, Edi Safitri, Kebangkitan Masjid Kampus di Yogyakarta: Eksklusif atau Inklusif, dalam Millah, Jurnal Studi Agama, Dialektika Agama dan Realitas Sosial Masyarakat (Vol. XV, No. 2, Februari 2016. Diterbitkan oleh: Program Pascasarjana Magister Studi Islam Fakultas IImu Aama Islam Universitas Islam Indonesia.

[17] Engku, Iskandar dan Siti Zubaidah, M.Ag. Sejarah Pendidikan Islam, Cet. I: PT. Remaja Rosdakarya, 2014.

[18] Giri, I Made Ariasa. Kontribusi Sarana Pendidikan Terhadap Kualitas Pendidikan Di Sekolah, Jurnal Penjaminan Mutu, Fakultas Dharma Acarya IHDN Denpasar.

[19] Jumaeda ST, La Rajab, Nur Khozin, et. al, Pemberdayaan Guru Pendidikan Agama Islam Melalui Peningkatan Kompetensi Guru Pada Tingkat Sekolah Dasar Di Waimital al-Iltizam: Jurnal Pendidikan 
Agama Islam, 2018.

[20] Kamus Besar Bahasa Indonesia Edisi IV, Jakarta: PT. Gramedia Pustaka Utama, 2008.

[21] Langer, Susanne Katherina Knauth. Philosophy in a New Key: A Study in the Symbolism of Reason, Rite and Art Harvard Univercity Press, 1997.

[22] Lemert, Charles. Social Theory: The Multicultural and Classic Readings Oxford: Westview Press, 1993.

[23] Lenia, Pramise \& Malta Nelisa, Tanggapan Masyarakat Terhadap Layanan Di Perpustakaan Masjid Ummi Nagari Alahan Panjang Kabupaten Solok, Jurnal. FBS Universitas Negeri Padang, 2014.

[24] Linton, Ralph. A Study of Man, an Introduction, Apleto-Century-Crofts. Inc., New York, 1936.

[25] McLaughlin, T. \& F. Lentricchia, Critical Terms for Literary Study Chicago: The University of Chcago press.

[26] Muliawan, Jasa Ungguh. Pendidikan Islam Integratif, Cet. I: Pustaka Pelajar, Yogyakarta, 2004.

[27] Mutiari, Dhani dkk. Masjid-Masjid Muhammadiyah Di Yogyakarta. Simposium Nasional Teknologi Terapan (SNTT) 22014.

[28] Nursaid, Nur Khozin, et al. Islamic Education Reorientation In Growing The Fitrah Goodness In The Era Of Globalization. al-Iltizam: Jurnal Pendidikan Agama Islam, 2019.

[29] Mutiari, Dhani dkk. Masjid-Masjid Muhammadiyah Di Yogyakarta. Simposium Nasional Teknologi Terapan (SNTT) 22014.

[30] Nursaid, Nur Khozin, et al. Islamic Education Reorientation In Growing The Fitrah Goodness In The Era Of Globalization. al-Iltizam: Jurnal Pendidikan Agama Islam, 2019.

[31] Purwanto, Nurtanio Agus. Kontribusi Pendidikan Bagi Pembangunan Ekonomi Negara, Jurnal manajemen pendidikan, no. 02/Th II/Oktober/2006.

[32] Pelupessy, Nur Khozin Abdullah; Husein, Saddam. Pembinaan 
Akhlak Mulia Mahasiswa Dalam Lembaga Dakwah Kampus (LDK) AlIzzah IAIN Ambon. al-IItizam: Jurnal Pendidikan Agama Islam, 2018.

[33] Sugiyono, Memahami Penelitian Kualtitatif Bandung: Alpabeta, 2005.

[34] --------, Metode Penelitian Kuantitatif Kualitatif dan $R$ \& $D$ Bandung: Alfabeta, 2009.

[35] Suharjanto, Didiek dkk, Kinerja Termal pada Masjid Amal Bhakti Muslim Pancasila, Spectra, Nomor 29 Volume XV Januari-Juni 2017.

[36] Sutarmadi, Ahmad. Visi, Misi dan langkah strategis; Pengurus Dewan Masjid Indonesia dan Pengelola Masjid, Jakarta: Logos Wacana IImu, 2002.

[37] Sutherland, Robert L. (dkk), Introductory Sociology, Ed. 6, J. B. Lippincott Company, Chicago, Philadelphia, New York, 1961.

[38] Tanjung, Syaiful Akhyar. http//www.yadmi.or.id masjid-sebagaipusat-pemberdayaan-ekonomi untukesehjateraan-umat-islamindonesia.

[39] Tauhid, Abu. Beberapa Aspek Pendidikan Islam, Yogyakarta: Sekretaris Jurusan Fakultas Tarbiyah IAIN Sunan Kalijaga, 1990.

[40] Tilaar, H. A. R. Manejemen Pendidikan Nasional, Bandung: PT. Remaja Rosdakarya, 1992.

[41] Toynbee, Bacalah Arnold. The Disintegrations of Civilization, dalam Theories of Sociaty, The Free Press, New York, 1965.

[42] Undang-Undang Republik Indonesia Nomor 20 tahun 2003 tentang Sistem Pendidikan Nasional.

[43] Wijaya, Cece Dkk, Upaya Pembaharuan Dalam Pendidikan Dan Pengajaran, Bandung: Remaja Rosdakarya, 1988.

[44] Yulian, Yoseph dan William Korllum, Social Problem Enlewood Clifis: New Jersey Prentical Hall, Inc, 1989.

[45] Yusuf, A. Muri. Metode Penelitian Kuantitatif, Kualitatif, dan Penelitian Gabungan, Cet. I; Jakarta: Prenadamedia Group, 2014.

[46] Zuly, Qodir dkk, Islam Kampus dalam Perubahan Politik Nasional: Studi Keislaman Masjid UGM, UNY, UIN Sunan Kalijaga, UII dan 
UMY Provinsi Daerah Istimewa Yogyakarta, Yogyakarta: Sekolah Pascasarjana Universitas Gajah Mada, 2010.

[47] 2Eprints.Uny.ac.id/8957/3/BAB ${ }^{\circ}$./ 202-08502241019, Pengertian Kontribusi, Akses Tanggal 12 Agustus 2013, Jam 16.30 W1B Pengertian Kontribusi.

[48] http://soeharto.co/daftar-masjid-yayasan-amalbhakti-muslimpancasila-yamp-provinsi-sumatera-selatan

[49] https://soeharto.co/999-masjid-yayasan-amal-bakti-muslim-pancasila/ 